\title{
Usulan Perbaikan Kualitas Pelayanan Kesehatan Dengan Metode Quality Function Deployment (QFD) di Poliklinik
}

\author{
Vera Devani*) dan Anisa Dwi Darma \\ Jurusan Teknik Industri, Fakultas Sains dan Teknologi, Universitas Islam Negeri Sultan Syarif Kasim Riau \\ Jl.H.R Soebrantas No. 155 KM. 18 Simpang Baru Panam Pekanbaru, 28293
}

DOI: 10.20961/performa.17.2.23520

\begin{abstract}
Abstrak
Poliklinik memberikan pelayanan perawatan kesehatan yang dikhususkan untuk perawatan pasien rawat jalan. Kualitas pelayanan mendorong pada peningkatan kepuasan pelanggan, sebagai upaya mempertahankan kepercayaan pelanggan terhadap layanan jasa. Penelitian ini bertujuan untuk menerjemahkan keinginan pasien menjadi tindakan dan proses dalam memenuhi kepuasan pasien, serta memberi usulan perbaikan terhadap pelayanan yang telah diberikan. Metode yang dapat digunakan untuk meningkatkan kualitas pelayanan adalah dengan menggunakan metode QFD (Quality Function Deployment) yaitu suatu metode yang digunakan untuk menerjemahkan kebutuhan konsumen ke dalam respon teknis sebagai upaya memperbaiki kualitas pelayanan. Berdasarkan hasil penelitian terdapat kesenjangan antara kinerja dan harapan pasien yang ditandai dengan nilai negatif. Voice of customer yang menjadi prioritas dalam melakukan perbaikan seperti atribut area parkir yang harus memadai, keramahan perawat dalam bekerja, ketersediaan kursi di ruang tunggu, kemudahan dalam proses administrasi, ketersediaan ruang sholat,dan lainnya. Usulan perbaikan yaitu memberikan pelayanan yang sama terhadap pasien, meningkatkan perhatian dan kesadaran dokter, memberikan informasi yang mudah dimengerti.
\end{abstract}

Kata kunci: interrelationship diagram, kualitas pelayanan, $Q F D$, tree diagram

\begin{abstract}
The polyclinic provides health care services specifically for outpatient care. Service quality encourages customer satisfaction, as an effort to maintain customer trust in services. This study aims to translate patient desires into actions and processes in meeting patient satisfaction, as well as suggest improvements to the services that have been given. The method that can be used to improve service quality is by using the Quality Function Deployment (QFD) method, QFD is a method used to translate customer requirement into technical responss in an effort to improve service quality. Based on the results of the study there is a gap between the performance and expectations of patients marked by negative values. Voice of customer is a priority in making improvements such as parking area attributes that must be adequate, nurses' friendliness in work, availability of seats in the waiting room, ease of administration process, availability of prayer rooms, and others. Proposed improvements is providing the same service to patients, increasing the attention and awareness of doctors, providing information that is easy to understand.
\end{abstract}

Keywords: interrelationship diagram, service quality, QFD, tree diagram

\section{Pendahuluan}

Rumah sakit sebagai sarana penunjang kesehatan merupakan objek sentral dalam memberikan pelayanan kepada masyarakat untuk meningkatkan kesehatan seluruh lapisan masyarakat. Dengan demikian rumah sakit dituntut untuk memberikan pelayanan terbaik dan dapat memenuhi tingkat kepuasan pasien sebagai subjek pemakai jasa layanan. Poliklinik merupakan bagian dari jenis pelayanan rumah sakit. Poliklinik menawarkan fasilitas perawatan kesehatan yang dikhususkan untuk perawatan pasien rawat jalan.

Menurut Tjiptono (1997) kualitas jasa merupakan sesuatu yang dipersepsikan oleh pelanggan. Pelanggan akan menilai kualitas sebuah jasa yang dirasakan berdasarkan apa yang mereka deskripsikan dalam benak mereka. Pelanggan akan beralih ke penyedia jasa lain yang lebih mampu memahami kebutuhan spesifik pelanggan dan memberikan layanan yang lebih baik, maka dari itu instansi penyedia jasa harus mempertimbangkan kualitas pelayanan untuk memenuhi kepuasan pelanggan dan melakukan manajemen terhadap kualitas pelayanan.

*Korespondensi : veradevani@gmail.com 
Secara konseptual manajemen kualitas dapat diterapkan baik pada barang maupun jasa, karena yang ditekankan dalam penerapan manajemen kualitas adalah perbaikan sistem kualitas. Manajemen kualitas atau manajemen kualitas terpadu didefinisikan sebagai upaya peningkatan kinerja secara terus menerus (countinuous performance improvement) (Wijaya, 2011).

Kualitas pelayanan mendorong pada peningkatan kepuasan pelanggan, sebagai upaya mempertahankan kepercayaan pelanggan terhadap layanan jasa, kualitas layanan yang baik akan menghasilkan tingkat kepuasan yang tinggi bagi pelanggan, sedangkan ketidakpuasan akan berdampak buruk bagi penilaian pelanggan terhadap kualitas layanan.

Service Quality adalah suatu alat atau metode yang digunakan untuk mengukur kualitas pelayanan berdasarkan lima dimensi kualitas pelayanan dengan menganalisa kesenjangan (gap) yang terjadi akibat ketidaksesuaian antara harapan dan persepsi pelanggan terhadap kualitas pelayanan yang diterima (Puspasari, 2013). Lima dimensi yang dimaksud adalah keandalan (reliability) yaitu kemampuan untuk melaksanakan pelayanan yang dijanjikan dengan segera, akurat dan memuaskan, kemudian ketanggapan (responsiveness) yaitu memberikan pelayanan dengan tanggap dan peduli terhadap keluhan pelanggan, selanjutnya jaminan (assurance) adalah kompetensi yang sedemikian hingga memberikan rasa aman dari bahaya, resiko, atau keraguan, empati (emphaty) adalah sifat dan kemampuan untuk memberikan perhatian penuh kepada pelanggan, dan terakhir yaitu dimensi berwujud (tangible) adalah wujud kenyataan secara fisik yang meliputi fasilitas, peralatan, pegawai dan sarana informasi atau komunikasi (Wijaya, 2011).

Metode seven new quality tools merupakan tujuh alat kualitas baru yang bersifat mendefinisikan masalah dengan data verbal dan mengumpulkan ide serta memformulasikan rencana. Metode ini digunakan untuk mengendalikan dan memperbaiki kualitas produk maupun jasa. Ada beberapa alat secara statistik yang digunakan pada metode ini yaitu Affinity Diagram, Interrelationship Diagram, Tree Diagram, Matrix Diagram, Matrix Data Analysis, Activity Network Diagram, dan Process Decision Program Chart (Suci, 2017).

Interrelationship diagram merupakan metode yang digunakan untuk mengklarifikasikan masalah yang kompleks dengan mempertimbangkan penyebab yang mungkin serta menentukan strategi yang tepat untuk setiap penyebab masalah yang berbeda (Wisnubroto, 2015). Diagram ini dapat menganalisis hubungan sebab dan akibat, sehingga dapat dengan mudah membedakan persoalan yang merupakan pemicu terjadinya masalah dan persoalan yang merupakan akibat dari masalah (Suci, 2017).

Tree diagram digunakan untuk memecahkan konsep apa saja secara lebih rinci ke dalam sub-sub komponen atau tingkat yang lebih rendah, yang dimulai dengan satu item yang bercabang menjadi dua atau lebih, masing-masing cabang kemudian bercabang lagi menjadi dua atau lebih dan seterusnya (Suci, 2017).

Berdasarkan survei pendahuluan yang telah dilakukan dengan menyebarkan kuesioner di RS. S terhadap pasien rawat jalan poliklinik spesialis mata, penyakit dalam, anak, dan kandungan terlihat bahwa persentase ketidakpuasan pelanggan cukup besar, dapat dilihat pada (Gambar 1) berikut ini:

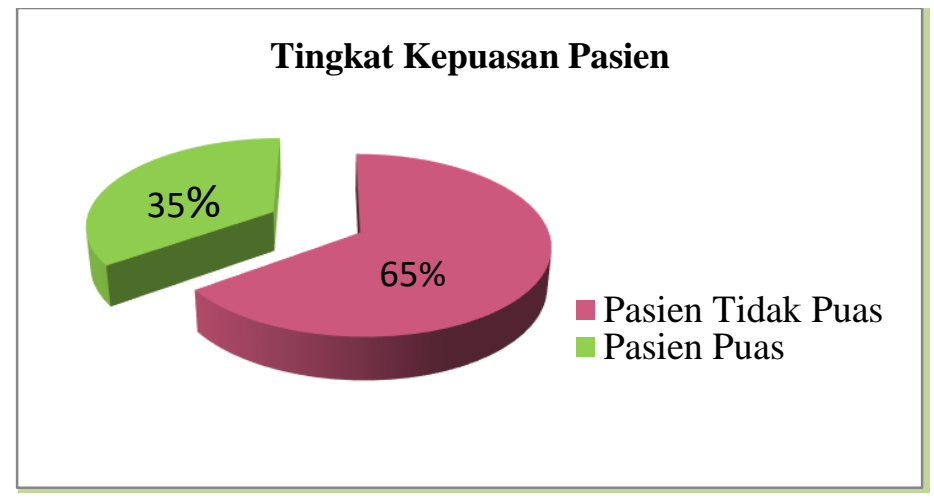

Gambar 1. Diagram Tingkat Kepuasan Pasien

Berdasarkan Gambar 1 terlihat bahwa kualitas pelayanan di poliklinik RS. S belum memenuhi kepuasan pelanggan seutuhnya. Pihak RS. S perlu secara cermat melakukan peningkatan kualitas pelayanan sebagai upaya untuk memenuhi keinginan pasien dan mempertahankan kepercayaan pelanggan terhadap pelayanan yang diberikan.

Salah satu metode yang dapat digunakan sebagai upaya meningkatkan kualitas pelayanan dalam memenuhi keinginan pasien adalah dengan menggunakan metode QFD (Quality Function Deployment). QFD adalah suatu teknik yang mampu mengidetifikasikan keinginan pelanggan dan merupakan praktik merancang proses sebagai tanggapan terhadap kebutuhan pelanggan. QFD menerjemahkan apa yang dibutuhkan pelanggan menjadi apa yang dihasilkan organisasi atau perusahaan (Wijaya, 2011).

Penelitian mengenai pengukuran kepuasan pelanggan dengan menggunakan metode QFD (Quality Function Deployment) telah banyak dilakukan sebelumnya seperti pada penelitian Magdalena (2013) yang bertujuan untuk mengetahui atribut-atribut apa yang menjadi acuan dalam meningkatkan kualitas pelayanan 
agar mengurangi kesenjangan antara pelayanan yang diharapkan dengan pelayanan yang dirasakan oleh pasien. Susila (2014) bertujuan untuk mengevaluasi kualitas layanan dan mengetahui variabel layanan yang harus diperbaiki untuk meningkatkan kualitas pelayanan.

Penelitian yang dilakukan di RS. S ini menggunakan metode QFD (Quality Function Deployment) yang bertujuan untuk menerjemahkan keinginan pasien menjadi tindakan dan proses dalam memenuhi kepuasan pasien, serta memberi usulan perbaikan terhadap pelayanan yang telah diberikan.

\section{Metode Penelitian}

Menentukan populasi dan jumlah sampel, populasi yang dimaksud adalah pasien pada poliklinik spesialis mata, penyakit dalam, anak, dan kandungan selama 2 tahun terakhir yaitu 2015-2016 sebanyak 101.561 pasien yang meliputi pasien BPJS, asuransi dan pasien umum. Sampel merupakan bagian dari populasi data yang dianggap mewakili populasi keseluruhan, dengan jumlah populasi yang telah diketahui, maka untuk menentukan jumlah sampel yang akan di ambil pada penelitian ini dengan cara pengambilan sampel menggunakan rumus Slovin didapatkan jumlah sampel sebanyak 100 sampel.

Pada tahapan pembuatan kuesioner langkah pertama yang dilakukan adalah mengumpulkan voice of customer dengan kuesioner terbuka yang kemudian akan diterjemahkan ke dalam dimensi servqual yang menjadi alat atau metode untuk menganalisa kesenjangan (gap) yang terjadi akibat ketidaksesuaian antara harapan dan persepsi pasien terhadap kualitas pelayanan yang diterima.

Tahapan uji validitas dan reliabilitas dilakukan terlebih dahulu sebelum instrument kuesioner dinyatakan valid dan reliabel, instrument dikatakan valid berarti menunjukkan alat ukur yang dipergunakan untuk mendapatkan data itu valid atau dapat digunakan untuk mengukur apa yang seharusnya diukur (Janti, 2014). Instrument dinyatakan valid jika angka korelasi ( $\mathrm{r}$ hitung) $>\mathrm{r}$ tabel maka pertanyaan tersebut valid dan sebaliknya. Sedangkan suatu alat ukur dikatakan reliabel jika memberikan nilai Cronbach Alpha > 0,60 yang artinya hasil pengukuran tetap konsisten bila diukur beberapa kali dengan alat ukur yang sama (Ghozali, 2002).

Tahapan pengolahan data yaitu dengan menggunakan metode QFD (Quality Function Deployment) yang dibentuk dengan matriks HOQ (House of Quality) untuk menerjemahkan voice of customer atau keinginan pasien ke dalam bahasa teknis dari pihak manajemen rumah sakit. Tahapan pengolahan matriks HOQ pada penelitian ini meliputi:

a. Improvement Ratio, digunakan untuk menunjukkan seberapa besar peningkatan layanan yang harus dilakukan pihak rumah sakit untuk memenuhi keinginan pasien. Nilai improvement ratio dihitung dari hasil pembagian nilai goal dengan nilai persepsi yang menginformasikan kepuasan pasien terhadap pelayanan yang diberikan. Pada bentuk matematis dapat dihitung menggunakan rumus berikut ini (Wicaksono, 2013):

$$
\text { Improvement Ratio }=\frac{\text { Goal }}{\text { Kinerja }}
$$

b. Sales Point, mengidentifikasi seberapa menguntungkan kebutuhan pasien tersebut berdampak pada pihak rumah sakit jika kebutuhan tersebut terenuhi. Nilai ini diperoleh dari hasil diskusi dengan pihak manajemen rumah sakit.

c. Raw Weight, bobot dari setiap atribut jasa diperoleh dari hasil perkalian faktor tingkat kepentingan, rasio perbaikan serta nilai sales point. Pada bentuk matematis dapat dihitung menggunakan rumus sebagai berikut (Wicaksono, 2013):

Raw Weight = Tingkat Kepentingan x Improvement Ratio x Sales Point

d. Normalized Raw Weight, normalisasi bobot setiap atribut jasa diperoleh dari hasil pembagian raw weight dengan total raw weight, dapat dihitung dengan menggunakan rumus berikut (Wicaksono, 2013):

Normalized Raw Weight $=\frac{\text { RawWeight }}{\text { RawWeight Total }} \times 100 \%$

Tahap analisa terhadap hasil pengolahan data, analisa dilakukan berdasarkan hasil perhitungan matriks HOQ (House of Quality) untuk mengetahui atribut-atribut apa saja yang harus segera diperbaiki, sebagai usulan perbaikan dari ketidakpuasan pasien terhadap atribut jasa tersebut penelitian ini menggunakan tools dari new seven tools yaitu interrelationship diagram yang dapat membantu menunjukkan sebab akibat suatu hubungan yang kompleks, sedangkan usulan untuk meningkatkan pelayanan di poliklinik menggunakan tree diagram. Hasil analisa digunakan untuk menarik kesimpulan dan sebagai bahan acuan untuk memberikan solusi upaya perbaikan kualitas pelayanan untuk meningkatkan kepuasan pasien.

\section{Hasil dan Pembahasan}

\subsection{Menentukan Voice of Customer (WHAT's)}

Voice of Customer merupakan keinginan dari setiap pasien terhadap suatu pelayanan yang dapat dilihat dari selisih penilaian antara kinerja dengan harapan dari pasien. Nilai negatif dari selisih tersebut menandakan kelemahan pelayanan karena berada di bawah harapan pasien. Hasil perhitungan gap antara kinerja dengan harapan dapat dilihat pada Tabel 1 berikut ini : 


\begin{tabular}{|c|c|c|c|c|}
\hline No & Pertanyaan & Kinerja & Harapan & Gap \\
\hline \multicolumn{5}{|c|}{ Tangible } \\
\hline 1 & Area parkir yang memadai & 2,54 & 4,39 & $-1,85$ \\
\hline 2 & Ketersediaan toilet laki-laki dan perempuan & 3,25 & 4,81 & $-1,56$ \\
\hline 3 & Ketersediaan ruangan sholat & 3,19 & 4,77 & $-1,58$ \\
\hline 4 & Ketersediaan kursi di ruang tunggu pasien & 3,16 & 4,67 & $-1,51$ \\
\hline 5 & Kebersihan ruangan praktek & 3,47 & 4,83 & $-1,36$ \\
\hline 6 & Kebersihan toilet & 3,10 & 4,20 & $-1,10$ \\
\hline 7 & Kebersihan ruang tunggu pasien & 3,22 & 4,46 & $-1,24$ \\
\hline 8 & Kebersihan ruang sholat & 3,45 & 4,80 & $-1,35$ \\
\hline \multicolumn{5}{|c|}{ Reliability } \\
\hline 9 & Kemudahan dalam proses administrasi & 3,21 & 4,80 & $-1,59$ \\
\hline 10 & Ketepatan kedatangan dokter & 3,33 & 4,88 & $-1,55$ \\
\hline 11 & Kecepatan pelayanan pemeriksaan pasien & 3,39 & 4,82 & $-1,43$ \\
\hline \multicolumn{5}{|c|}{ Responsiveness } \\
\hline 12 & $\begin{array}{l}\text { Kinerja karyawan dalam memberikan informasi } \\
\text { kepada pasien }\end{array}$ & 3,26 & 4,74 & $-1,48$ \\
\hline 13 & $\begin{array}{l}\text { Tenaga medis (dokter dan perawat) cepat tanggap } \\
\text { merespon keluhan pasien }\end{array}$ & 3,16 & 4,72 & $-1,56$ \\
\hline 14 & Karyawan cepat tanggap merespon keluhan pasien & 3,08 & 4,5 & $-1,42$ \\
\hline \multicolumn{5}{|c|}{ Assurance } \\
\hline 15 & $\begin{array}{l}\text { Kesamaan pemberian pelayanan kepada pasien (BPJS } \\
\text { dan Non BPJS) }\end{array}$ & 3,28 & 4,63 & $-1,35$ \\
\hline 16 & Keamanan lingkungan rumah sakit & 3,78 & 4,77 & $-0,99$ \\
\hline 17 & Keramahan dokter dalam bekerja & 3,80 & 4,16 & $-0,36$ \\
\hline 18 & Keramahan perawat dalam bekerja & 3,02 & 4,56 & $-1,54$ \\
\hline 19 & Keramahan karyawan dalam bekerja & 3,04 & 4,49 & $-1,45$ \\
\hline \multicolumn{5}{|c|}{ Emphaty } \\
\hline 20 & Perhatian dokter dalam menangani keluhan pasien & 3,89 & 4,86 & $-0,97$ \\
\hline 21 & Perhatian perawat dalam menangani keluhan pasien & 3,46 & 4,85 & $-1,39$ \\
\hline 22 & Perhatian karyawan dalam menangani keluhan pasien & 3,30 & 4,75 & $-1,45$ \\
\hline
\end{tabular}

Berdasarkan tabel 1 terlihat bahwa selisih antara penilaian kinerja dengan nilai harapan pada setiap atribut jasa menunjukkan nilai negatif yang artinya terjadi kesenjangan antara kinerja dengan harapan pasien yang menandakan masih lemahnya pelayanan yang dirasakan pelanggan karena berada di bawah harapan.

\subsection{Mengembangkan Prioritiezed Customer Requirement}

Tahapan mengembangkan prioritiezed customer requirement adalah sebagai berikut:

a. Perhitungan Improvement Ratio

Hasil rekapitulasi perhitungan improvement ratio dapat dilihat pada Tabel 2 berikut ini:

Tabel 2. Nilai Improvement Ratio (IR)

\begin{tabular}{clccc}
\hline No & \multicolumn{1}{c}{ Voice of Customer } & Kinerja & $\begin{array}{c}\text { Goal } \\
\text { (Harapan) }\end{array}$ & IR \\
\hline \multicolumn{2}{c}{ Tangible } & & & \\
1 & Area parkir yang memadai & 2,54 & 4,39 & 1,73 \\
2 & Ketersediaan toilet laki-laki dan & 3,25 & 4,81 & 1,48 \\
$\quad$ perempuan & 3,19 & 4,77 & 1,50 \\
3 & Ketersediaan ruangan sholat & 3,16 & 4,67 & 1,48 \\
4 & Ketersediaan kursi di ruang tunggu & 3,47 & 4,83 & 1,39 \\
5 & pasien & 3,10 & 4,20 & 1,35 \\
6 & Kebersihan ruangan praktek & 3,22 & 4,46 & 1,39 \\
7 & Kebersihan toilet & 3,45 & 4,80 & 1,39 \\
8 & Kebersihan ruang tunggu pasien & 3,21 & 4,80 & 1,50 \\
Reliability & 3,33 & 4,88 & 1,47 \\
9 & Kemudahan dalam proses administrasi & 3,39 & 4,82 & 1,42 \\
10 & Ketepatan kedatangan dokter & & & \\
$11 \quad$ Kecepatan pelayanan pemeriksaan & pasien & & & \\
Responsiveness &
\end{tabular}




\begin{tabular}{|c|c|c|c|c|}
\hline 12 & $\begin{array}{l}\text { Kinerja karyawan dalam memberikan } \\
\text { informasi kepada pasien }\end{array}$ & 3,26 & 4,74 & 1,45 \\
\hline 13 & $\begin{array}{l}\text { Tenaga medis (dokter dan perawat) } \\
\text { cepat tanggap merespon keluhan pasien }\end{array}$ & 3,16 & 4,72 & 1,49 \\
\hline 14 & $\begin{array}{l}\text { Karyawan cepat tanggap merespon } \\
\text { keluhan pasien }\end{array}$ & 3,08 & 4,5 & 1,46 \\
\hline \multicolumn{5}{|c|}{ Assurance } \\
\hline 15 & $\begin{array}{l}\text { Kesamaan pemberian pelayanan kepada } \\
\text { pasien (BPJS dan Non BPJS) }\end{array}$ & 3,28 & 4,63 & 1,41 \\
\hline 16 & Keamanan lingkungan rumah sakit & 3,78 & 4,77 & 1,26 \\
\hline 17 & Keramahan dokter dalam bekerja & 3,80 & 4,16 & 1,09 \\
\hline 18 & Keramahan perawat dalam bekerja & 3,02 & 4,56 & 1,51 \\
\hline 19 & Keramahan karyawan dalam bekerja & 3,04 & 4,49 & 1,48 \\
\hline \multicolumn{5}{|c|}{ Emphaty } \\
\hline 20 & $\begin{array}{l}\text { Perhatian dokter dalam menangani } \\
\text { keluhan pasien }\end{array}$ & 3,89 & 4,86 & 1,25 \\
\hline 21 & $\begin{array}{l}\text { Perhatian perawat dalam menangani } \\
\text { keluhan pasien }\end{array}$ & 3,46 & 4,85 & 1,40 \\
\hline 22 & $\begin{array}{l}\text { Perhatian karyawan dalam menangani } \\
\text { keluhan pasien }\end{array}$ & 3,30 & 4,75 & 1,44 \\
\hline
\end{tabular}

Berdasarkan Tabel 2 nilai improvement ratio menunjukkan bahwa atribut jasa yang berada di range 11,5 artinya perlu dilakukan perbaikan segera terhadap variabel tersebut, sedangkan atribut jasa $>1,5$ artinya harus dilakukan perbaikan menyeluruh terhadap variabel tersebut (Wicaksono, 2013).

\section{b. Menentukan Sales Point}

Nilai sales point didapat dari hasil diskusi dengan pihak manajemen RS. S terhadap masing-masing keinginan pasien. Berdasarkan hasil diskusi yang telah dilakukan nilai sales point untuk masing-masing variabel adalah 1,5 karena menurut pihak manajemen semua variabel penting dalam upaya meningkatkan kepuasan pelanggan. Tabel 3 di bawah ini menunjukkan nilai sales point untuk setiap atribut:

Tabel 3. Nilai Sales Point Tiap Atribut Jasa di RS. S

\begin{tabular}{|c|c|c|}
\hline No & Pertanyaan & Sales Point \\
\hline \multicolumn{3}{|c|}{ Tangible } \\
\hline 1 & Area parkir yang memadai & 1,5 \\
\hline 2 & Ketersediaan toilet laki-laki dan perempuan & 1,5 \\
\hline 3 & Ketersediaan ruangan sholat & 1,5 \\
\hline 4 & Ketersediaan kursi di ruang tunggu pasien & 1,5 \\
\hline 5 & Kebersihan ruangan praktek & 1,5 \\
\hline 6 & Kebersihan toilet & 1,5 \\
\hline 7 & Kebersihan ruang tunggu pasien & 1,5 \\
\hline 8 & Kebersihan ruang sholat & 1,5 \\
\hline \multicolumn{3}{|c|}{ Reliability } \\
\hline 9 & Kemudahan dalam proses administrasi & 1,5 \\
\hline 10 & Ketepatan kedatangan dokter & 1,5 \\
\hline 11 & Kecepatan pelayanan pemeriksaan pasien & 1,5 \\
\hline \multicolumn{3}{|c|}{ Responsiveness } \\
\hline 12 & $\begin{array}{l}\text { Kinerja karyawan dalam memberikan informasi kepada } \\
\text { pasien }\end{array}$ & 1,5 \\
\hline 13 & $\begin{array}{l}\text { Tenaga medis (dokter dan perawat) cepat tanggap merespon } \\
\text { keluhan pasien }\end{array}$ & 1,5 \\
\hline 14 & Karyawan cepat tanggap merespon keluhan pasien & 1,5 \\
\hline \multicolumn{3}{|c|}{ Assurance } \\
\hline 15 & $\begin{array}{l}\text { Kesamaan pemberian pelayanan kepada pasien (BPJS dan } \\
\text { Non BPJS) }\end{array}$ & 1,5 \\
\hline 16 & Keamanan lingkungan rumah sakit & 1,5 \\
\hline 17 & Keramahan dokter dalam bekerja & 1,5 \\
\hline 18 & Keramahan perawat dalam bekerja & 1,5 \\
\hline 19 & Keramahan karyawan dalam bekerja & 1,5 \\
\hline \multicolumn{3}{|c|}{ Emphaty } \\
\hline 20 & Perhatian dokter dalam menangani keluhan pasien & 1,5 \\
\hline 21 & Perhatian perawat dalam menangani keluhan pasien & 1,5 \\
\hline 22 & Perhatian karyawan dalam menangani keluhan pasien & 1,5 \\
\hline
\end{tabular}

\section{c. Perhitungan Raw Weight}

Hasil rekapitulasi perhitungan nilai raw weight untuk setiap atribut adalah sebagai: 
Tabel 4. Rekapitulasi Hasil Perhitungan Raw Weight

\begin{tabular}{|c|c|c|c|c|}
\hline $\begin{array}{c}\text { Atribut } \\
\text { Jasa }\end{array}$ & $\begin{array}{c}\text { Tingkat } \\
\text { Kepentingan }\end{array}$ & $\begin{array}{c}\text { Improvement } \\
\text { Ratio } \\
\end{array}$ & Sales Point & Raw Weight \\
\hline 1 & 4,01 & 1,73 & 1,5 & 10,41 \\
\hline 2 & 4,24 & 1,48 & 1,5 & 9,41 \\
\hline 3 & 4,64 & 1,5 & 1,5 & 10,04 \\
\hline 4 & 4,61 & 1,48 & 1,5 & 10,23 \\
\hline 5 & 4,33 & 1,39 & 1,5 & 9,03 \\
\hline 6 & 4,15 & 1,35 & 1,5 & 8,40 \\
\hline 7 & 4,45 & 1,39 & 1,5 & 9,28 \\
\hline 8 & 4,26 & 1,39 & 1,5 & 8,88 \\
\hline 9 & 4,47 & 1,5 & 1,5 & 10,06 \\
\hline 10 & 4,46 & 1,47 & 1,5 & 9,83 \\
\hline 11 & 4,52 & 1,42 & 1,5 & 9,63 \\
\hline 12 & 4,32 & 1,45 & 1,5 & 9,40 \\
\hline 13 & 4,41 & 1,49 & 1,5 & 9,86 \\
\hline 14 & 4,29 & 1,46 & 1,5 & 9,40 \\
\hline 15 & 4,45 & 1,41 & 1,5 & 9,41 \\
\hline 16 & 4,32 & 1,26 & 1,5 & 8,16 \\
\hline 17 & 4,16 & 1,09 & 1,5 & 6,80 \\
\hline 18 & 4,56 & 1,51 & 1,5 & 10,33 \\
\hline 19 & 4,49 & 1,48 & 1,5 & 9,97 \\
\hline 20 & 4,60 & 1,25 & 1,5 & 8,63 \\
\hline 21 & 4,56 & 1,4 & 1,5 & 9,58 \\
\hline 22 & 4,51 & 1,44 & 1,5 & 9,74 \\
\hline \multicolumn{4}{|c|}{ Total Raw Weight } & 206,4639 \\
\hline
\end{tabular}

\section{d. Perhitungan Normalized Raw Weight}

Rekapitulasi hasil perhitungan nilai normalized raw weight untuk setiap atribut voice of customer adalah sebagai berikut:

Tabel 5. Rekapitulasi Hasil Perhitungan Normalized Raw Weight

\begin{tabular}{clc}
\hline No & \multicolumn{1}{c}{ Voice of Customer } & $\begin{array}{c}\text { Normalized Raw } \\
\text { Weight }\end{array}$ \\
\hline 1 & Area parkir yang memadai & $5,04 \%$ \\
2 & Keramahan perawat dalam bekerja & $5,00 \%$ \\
3 & Ketersediaan kursi di ruang tunggu pasien & $4,96 \%$ \\
4 & Kemudahan dalam proses administrasi & $4,87 \%$ \\
5 & Ketersediaan ruangan sholat & $4,86 \%$ \\
6 & Keramahan karyawan dalam bekerja & $4,83 \%$ \\
7 & Tenaga medis (dokter dan perawat) cepat & $4,77 \%$ \\
8 & tanggap merespon keluhan pasien & $4,76 \%$ \\
9 & Ketepatan kedatangan dokter & Perhatian karyawan dalam menangani \\
10 & keluhan pasien & Kecepatan pelayanan pemeriksaan pasien \\
11 & $\begin{array}{l}\text { Perhatian perawat dalam menangani } \\
\text { keluhan pasien }\end{array}$ & $4,72 \%$ \\
12 & $\begin{array}{l}\text { Kesamaan pemberian pelayanan kepada } \\
\text { pasien (BPJS dan Non BPJS) }\end{array}$ & $4,64 \%$ \\
13 & $\begin{array}{l}\text { Ketersediaan toilet laki-laki dan } \\
\text { perempuan }\end{array}$ & $4,56 \%$ \\
14 & $\begin{array}{l}\text { Kinerja karyawan dalam memberikan } \\
\text { informasi kepada pasien }\end{array}$ & $4,56 \%$ \\
15 & $\begin{array}{l}\text { Karyawan cepat tanggap merespon } \\
\text { keluhan pasien }\end{array}$ & $4,55 \%$ \\
Kebersihan ruang tunggu pasien & $4,55 \%$ \\
& & $4,49 \%$ \\
&
\end{tabular}




\begin{tabular}{lll}
17 & Kebersihan ruangan praktek & $4,37 \%$ \\
18 & Kebersihan ruang sholat & $4,30 \%$ \\
19 & Perhatian dokter dalam menangani & $4,18 \%$ \\
20 & keluhan pasien & $4,07 \%$ \\
21 & Kebersihan toilet & $3,95 \%$ \\
22 & Keramanan lingkungan rumah sakit & $3,29 \%$ \\
\hline
\end{tabular}

\subsection{Menentukan Technical Requirement (HOW's)}

Hasil dari penerjemahaan voice of customer menjadi technical requirement atau respon teknis dapat dilihat pada Tabel 6 berikut ini:

Tabel 6. Technical Requirement (HOW's)

\begin{tabular}{cl}
\hline No. & \multicolumn{1}{c}{ Technical Requirement $(\mathrm{HOWs})$} \\
\hline 1 & Mengembangkan fasilitas (area parkir, toilet, ruang sholat, ruang tunggu) \\
2 & Meningkatkan pelayanan cleaning service \\
3 & Memberikan informasi yang mudah dimengerti \\
4 & Meningkatkan kesiplinan dokter \\
5 & Meningkatkan keakuratan dalam melakukan diagnose \\
6 & Meningkatkan perhatian dan kesadaran dokter \\
7 & Meningkatkan perhatian dan kesadaran perawat \\
8 & Meningkatkan perhatian dan kesadaran karyawan \\
9 & Meningkatkan kemampuan tenaga medis (dokter dan perawat) \\
10 & Meningkatkan kemampuan karyawan \\
11 & Memberikan pelayanan yang sama terhadap pasien \\
12 & Meningkatkan keamanan lingkungan \\
13 & Meningkatkan keramahan dan kesopanan dokter \\
14 & Meningkatkan keramahan dan kesopanan perawat \\
15 & Meningkatkan keramahan dan kesopanan karyawan \\
\hline
\end{tabular}

\subsection{Matriks HOQ Customer Requirement (WHAT's) to Technical Requirement (HOW's)}

Matriks HOQ (House of Quality) customer requirement atau kebutuhan pelanggan dengan technical requirement kebutuhan teknis dapat dilihat pada Gambar 2: 


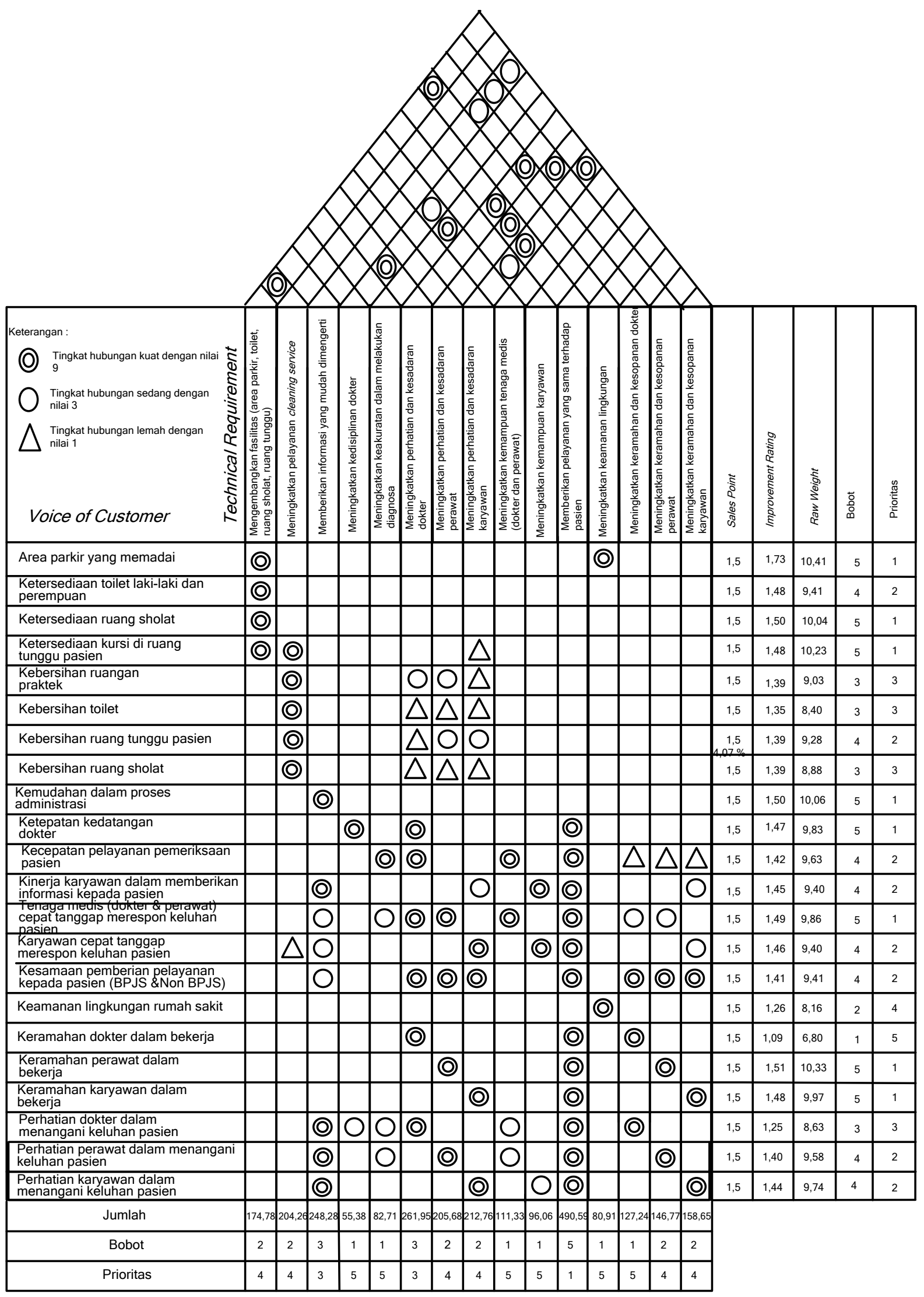

Gambar 2. HOQ Customer Requirement to Technical Requirement

Berdasarkan perhitungan nilai VOC ditentukan nilai interval kelas Raw Weight prioritas perbaikan seperti pada Tabel 7 berikut ini:

Tabel 7. Interval dalam menentukan prioritas Voice of Customer (VOC)

\begin{tabular}{ccc}
\hline Interval Raw Weight & Bobot & Prioritas \\
$6,79-7,53$ & 1 & 5 \\
$7,54-8,28$ & 2 & 4 \\
$8,29-9,03$ & 3 & 3 \\
$9,04-9,78$ & 4 & 2 \\
$9,79-10,53$ & 5 & 1 \\
\hline
\end{tabular}


Berdasarkan perhitungan Technical Requirement (TR) diperoleh tindakan yang menjadi prioritas perbaikan berdasarkan nilai interval kelas Technical Requirement (TR) sebagai berikut:

Tabel 8. Interval dalam menentukan prioritas Technical Requirement (TR)

\begin{tabular}{ccc} 
Interval Raw Weight & Bobot & Prioritas \\
$55,38-142,42$ & 1 & 5 \\
$142,43-229,47$ & 2 & 4 \\
$229,48-316,52$ & 3 & 3 \\
$316,53-403,57$ & 4 & 2 \\
$403,58-490,62$ & 5 & 1 \\
\hline
\end{tabular}

Hubungan keterkaitan sebab-akibat suatu hubungan dapat dijelaskan dengan menggunakan Interrelationship Diagram. Interrelationship Diagram digunakan untuk mengetahui berbagai masalah sehingga dapat membedakan persoalan apa yang menjadi pemicu permasalahan tersebut. Hubungan keterkaitan penyebab masalah ketidakpuasan dari urutan voice of customer berdasarkan prioritas 1 adalah sebagai berikut:

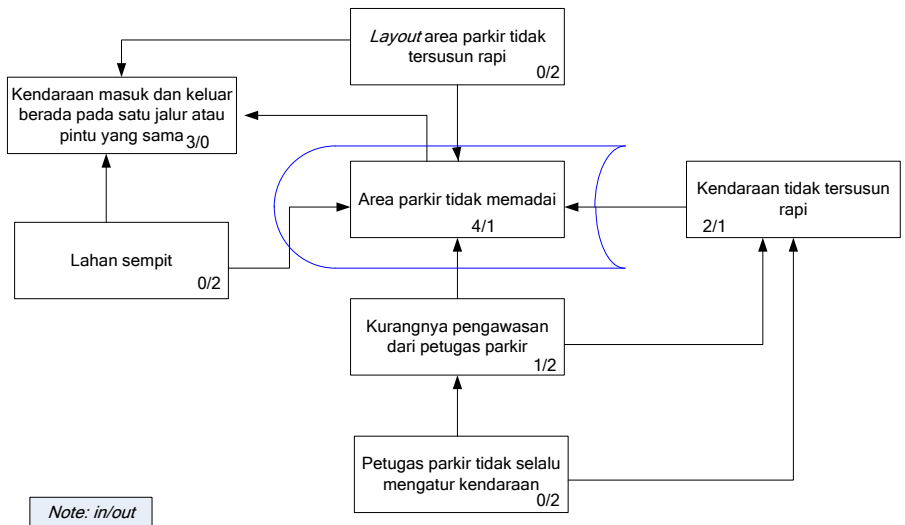

Gambar 3. Interrelationship Diagram Area Parkir Tidak Memadai

Berdasarkan Gambar 3 di atas terlihat bahwa "area parkir yang tidak memadai" merupakan akibat dari beberapa akar penyebab yang terjadi, karena memiliki empat garis panah masuk dan satu garis panah keluar, yang artinya memiliki akar penyebab terbanyak dibandingkan faktor penyebab yang lain.

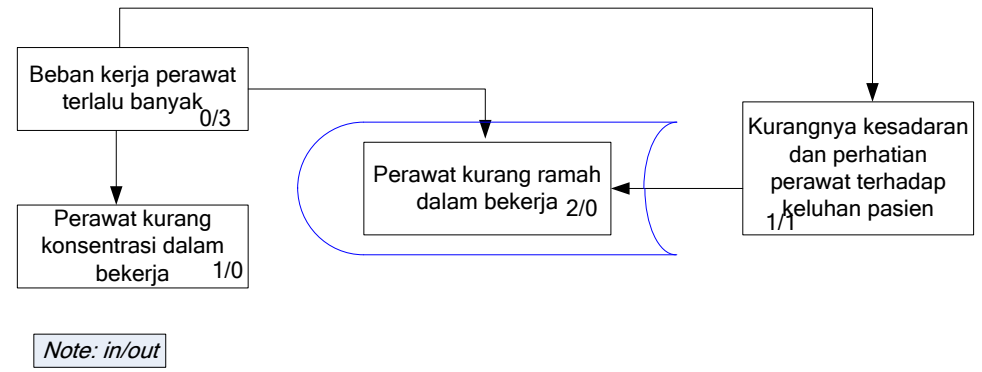

Gambar 4. Interrelationship Diagram Perawat Kurang Ramah dalam Bekerja

Berdasarkan Gambar 4 di atas terlihat bahwa "perawat kurang ramah dalam bekerja” merupakan akibat dari beberapa akar penyebab yang terjadi, karena memiliki dua garis panah masuk yang artinya memiliki akar penyebab terbanyak dibandingkan faktor penyebab yang lain.

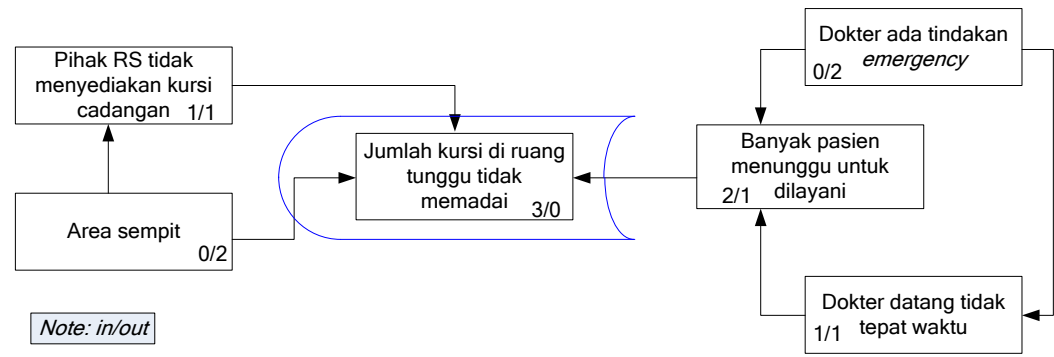

Gambar 5. Interrelationship Diagram Jumlah Kursi di Ruang Tunggu Tidak Memadai

Berdasarkan Gambar 5 di atas terlihat bahwa "jumlah kursi di ruang tunggu tidak memadai" merupakan akibat dari beberapa akar penyebab yang terjadi, karena memiliki tiga garis panah masuk yang artinya memiliki akar penyebab terbanyak dibandingkan faktor penyebab yang lain. 


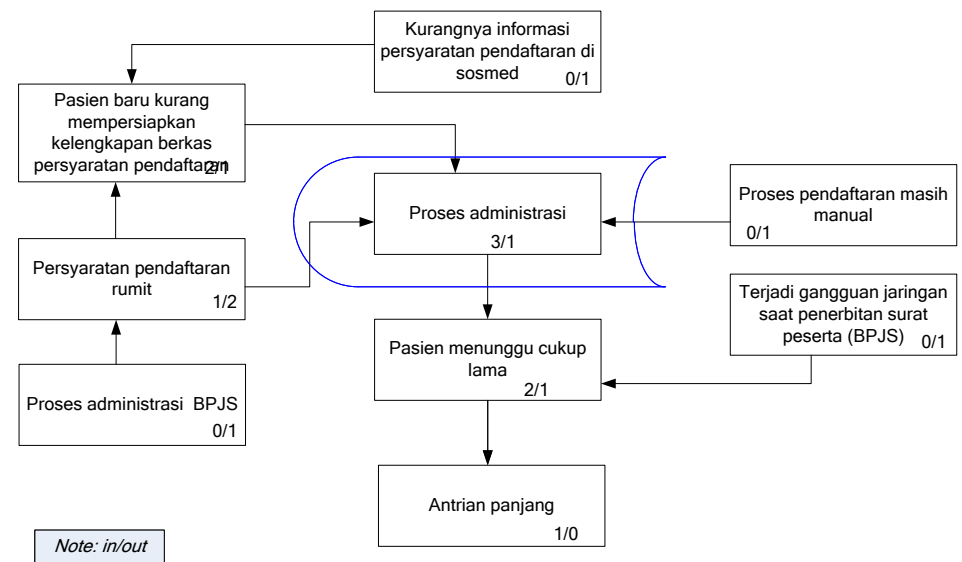

Gambar 6. Interrelationship Diagram Proses Administrasi

Berdasarkan Gambar 6 di atas terlihat bahwa "proses administrasi rumit" merupakan akibat dari beberapa akar penyebab yang terjadi, karena memiliki tiga garis panah masuk dan satu garis panah keluar, yang artinya memiliki akar penyebab terbanyak dibandingkan faktor penyebab yang lain.

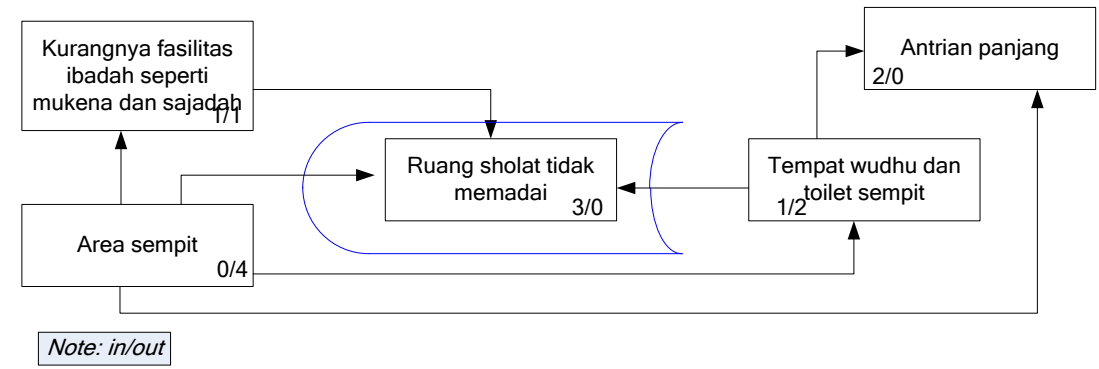

Gambar 7. Interrelationship Diagram Ruang Sholat Tidak Memadai

Berdasarkan Gambar 7 di atas terlihat bahwa "ruang sholat tidak memadai" merupakan akibat dari beberapa akar penyebab yang terjadi, karena memiliki tiga garis panah masuk yang artinya memiliki akar penyebab terbanyak dibandingkan faktor penyebab yang lain.

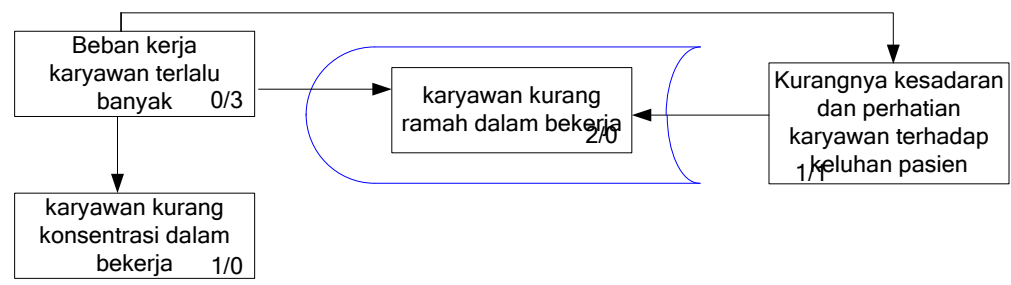

Gambar 8. Interrelationship Diagram Karyawan Kurang Ramah dalam Bekerja

Berdasarkan Gambar 8 di atas terlihat bahwa "karyawan kurang ramah dalam bekerja" merupakan akibat dari beberapa akar penyebab yang terjadi, karena memiliki dua garis panah masuk yang artinya memiliki akar penyebab terbanyak dibandingkan faktor penyebab yang lain.

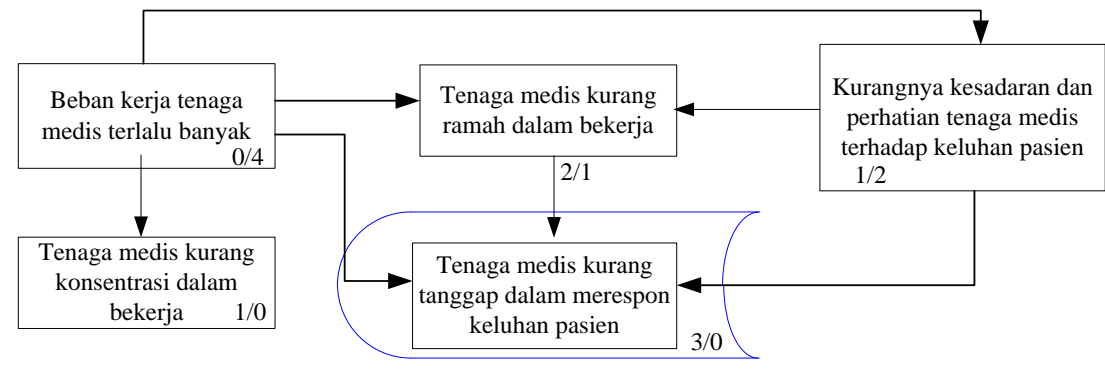

Note: in/out

Gambar 9. Interrelationship Diagram Tenaga Medis Kurang Tanggap dalam Merespon Keluhan Pasien

Berdasarkan Gambar 9 di atas terlihat bahwa "tenaga medis kurang tanggap dalam merespon keluhan pasien" merupakan akibat dari beberapa akar penyebab yang terjadi, karena memiliki tiga garis panah masuk yang artinya memiliki akar penyebab terbanyak dibandingkan faktor penyebab yang lain. 


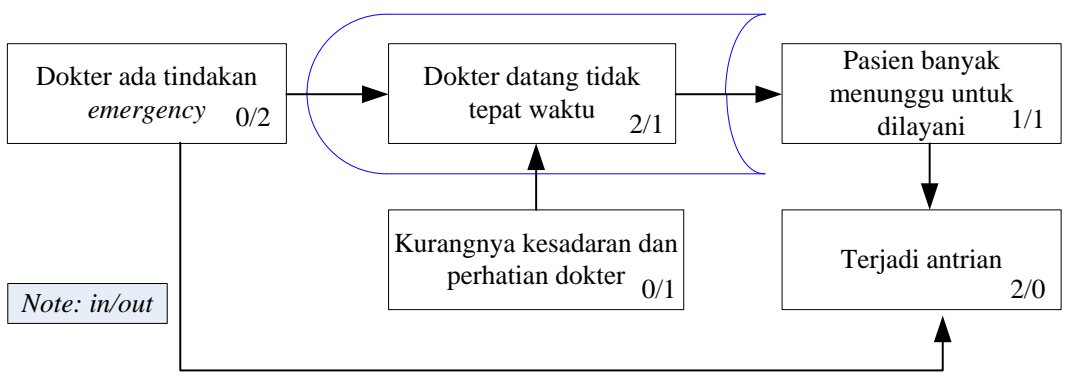

Gambar 10. Interrelationship Diagram Ketepatan Kedatangan Dokter

Berdasarkan Gambar 10 di atas terlihat bahwa "dokter datang tidak tepat waktu" merupakan akibat dari beberapa akar penyebab yang terjadi, karena memiliki dua garis panah masuk dan satu garis panah keluar yang artinya memiliki akar penyebab terbanyak dibandingkan faktor penyebab yang lain.

Usulan perbaikan dilakukan dengan menerjemahkan keinginan pasien ke dalam bahasa teknis, sebagai bentuk pemecah masalah voice of customer dibagi ke dalam lima kategori dimensi servqual yang akan dijabarkan menggunakan tree diagram (Gambar 11) berikut ini:

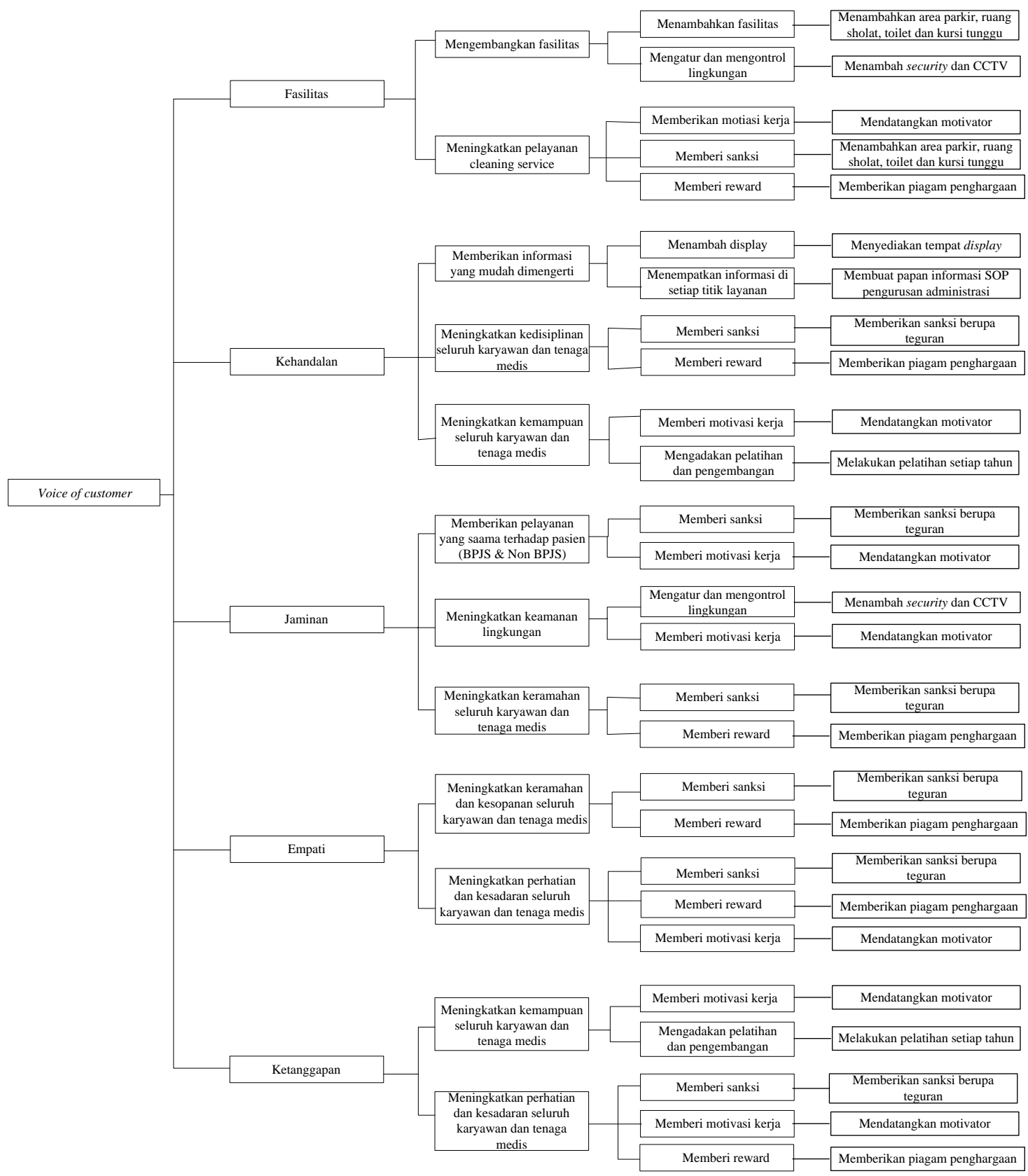

Gambar 11. Tree Diagram dari Voice of Customer 


\section{Kesimpulan}

Terdapat kesenjangan antara kinerja dan harapan pasien yang ditandai dengan nilai negatif, terdapat 22 atribut voice of customer (VOC) yang perlu dilakukan perbaikan. Voice of customer yang menjadi prioritas perbaikan yang harus dilakukan pihak rumah sakit seperti atribut area parkir tidak memadai yang disebabkan oleh kendaraan ke luar masuk berada pada satu jalur atau pintu yang sama sehingga menyebabkan ketidaknyamanan penggunanya, keramahan perawat dalam bekerja, ketersediaan kursi di ruang tunggu, kemudahan dalam proses administrasi, ketersediaan ruang sholat dan lainnya. Usulan perbaikan sebagai upaya dalam memenuhi kebutuhan pasien terhadap pelayanan rumah sakit untuk meningkatkan kepuasan pasien berdasarkan prioritas utama yaitu memberikan pelayanan yang sama terhadap pasien dengan memberikan motivasi kerja serta memberikan sanksi berupa teguran, SP 1,2,3 dan PHK serta reward berupa piagam penghargaan setiap bulannya kepada tenaga medis dan karyawan yang disiplin. Target dari kebutuhan proses ini adalah agar karyawan tidak membeda-bedakaan setiap pelayanan yang diberikan kepada setiap pasien bpjs dan non bpjs.

Technical Requirement yang harus dilakukan adalah meningkatkan perhatian dan kesadaran dokter dalam bekerja yaitu dengan memberikan motivasi kerja seperti mamberikan sanksi pada dokter yang tidak ramah dalam bekerja dan memberikan reward atau penghargaan pada setiap dokter yang ramah dalam bekerja. Target dari proses ini adalah agar dokter mampu bekerja dengan ramah dan penuh perhatian dan kesadaran dalam melayani pasien, memberikan informasi yang mudah dimengerti dengan menambahkan display yang jelas sebagai bentuk petunjuk terhadap suatu informasi dan menempatkan informasi di setiap titik layanan. Target dari proses ini adalah untuk memudahkan pasien dalam mendapatkan informasi yang jelas.

\section{Daftar Pustaka}

Ghozali, Imam. (2002). Aplikasi analisis multivariate dengan program SPSS, Semarang, badan penerbit universitas diponegoro.

Janti, Suhar. (2014). Analisis Validitas dan Reliabilitas dengan Skala Likert Terhadap Pengembangan Si/Ti dalam Penentuan Pengambilan Keputusan Penerapan Strategic Planning pada Industri Garmen. Prosiding Seminar Nasional Aplikasi Sains \& Teknologi (SNAST). Jakarta.

Magdalena, Marito, dkk (2013) Peningkatan Kualitas Pelayanan dengan Menggunakan Metode Quality Function Deployment (Qfd) Di Rumah Sakit XYZ. E-Jurnal Teknik Industri FT USU Vol 3, No. 2, Oktober 2013 pp. 31-37. Medan.

Puspasari, Maya Arlini dan Nia Kurniasih. (2013). Pengembangan Kualitas Pelayanan Produk Telekomunikasi Selular Diatas Kapal Menggunakan Metode Service Quality \& Quality Function Deployment. Jurnal Teknik Industri ISSN 2088-4842. Jakarta.

Suci, Yurin Febria, dkk. (2017) Penggunaan Metode Seven New Quality Tools dan Metode DMAIC Six Sigma pada Penerapan Pengendalian Kualitas Produk (Studi Kasus : Roti Durian Panglima Produksi PT. Panglima Roqiiqu Group Samarinda). Jurnal Eksponensial Volume 8, Nomor 1, Mei 2017 ISSN 20857829. Samarinda.

Susila, Gede Putu Agus Jana, dkk. (2014). Implementasi Quality Function Deployment (QFD) untuk Meningkatkan Layanan Publik di RSUD Kabupaten Buleleng Bali. Jurnal Ilmu Sosial dan Humaniora Vol.3, No.2, Oktober 2014 ISSN: 2303-2898. Bali.

Tjiptono, Fandy. (1997) Total Quality Service. Andi. Yogyakarta.

Wicaksono, Adhitya Wahyu. (2013). Penerapan Metode QFD (Quality function Deployment) pada Rencana Pengembangan Sekolah di SMKN 2 Yogyakarta. (Skripsi), Fakultas Teknik, Universitas Negeri Yogyakarta. Yogyakarta.

Wijaya, Toni. (2011), Manajemen Kualitas Jasa, Edisi 1, PT Indeks, Jakarta.

Wisnubroto, petrus dan Arya Rukmana (2015). Pengendalian Kualitas Produk dengan Pendekatan Six Sigma dan Analisis Kaizen Serta New Seven Tools Sebagai Usaha Pengurangan Kecacatan Produk. Jurnal Teknologi, Volume 8 Nomor 1, Juni 2015, 65-74. Yogyakarta. 